METAPHASE CHROMOSOME ABERRATIONS AS MARKERS OF RADIATION EXPOSURE AND DOSE

A. L. Brooks

M. A. Khan

R. F. Jostes

F. T. Cross

October 1992

Presented at the 1992 Thirty-First Hanford Symposium October 20-23, 1992 Richland, Washington

Prepared for the U.S. Department of Energy under Contract DE-ACO6-76RLO 1830

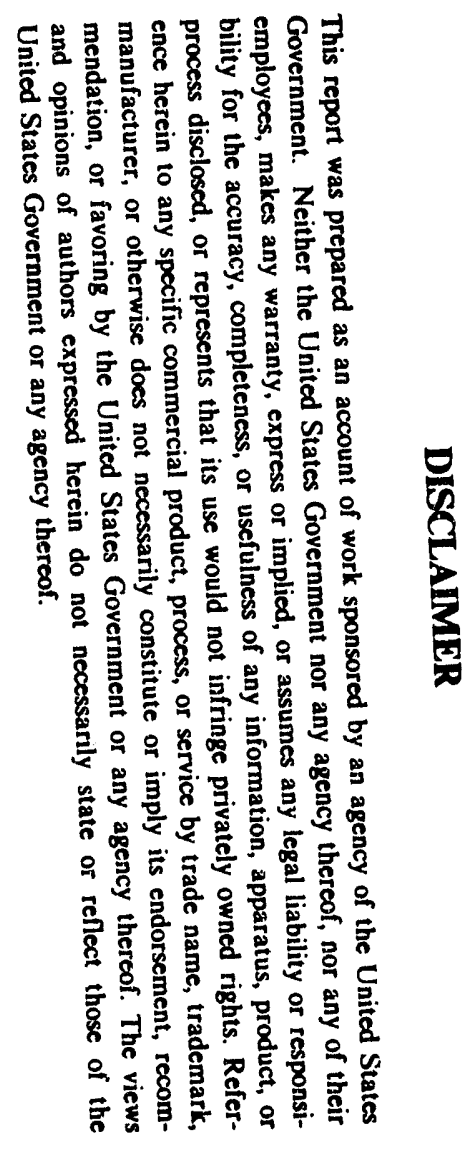

MAviter

Pacific Northwest Laboratory

Richland, Washington 99352

DOREIVED

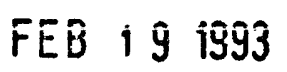




\section{Metaphase Chromosome Aberrations as Markers of Radiation Exposure and Dose}

\section{Abstract}

Chromosome aberration frequency provides the most reliable biological marker of dose for detecting acute accidental radiation exposure. Significant radiation-induced changes in the frequency of chromosome aberrations can be detected at very low doses (LLoyd et al. 1992). Our paper provides information on using molecular chromosome probes "paints" to score chromosome damage and illustrates how technical advances make it possible to understand mechanisms involved during formation of chromosome aberrations. In animal studies chromosome aberrations provide a method to relate cellular damage to cellular dose. Using an In vivo/ln vitro approach aberrations provided a biological marker of dose from radon progeny exposure which was used to convert WLM to dose in rat tracheal epithelial cells. Injection of Chinese hamsters with ${ }^{144} \mathrm{Ce}$ which produced a low dose rate exposure of bone marrow to either low-LET radiation increased the sensitivity of the cells to subsequent external exposure to $60 \mathrm{Co}$. These studies demonstrated the usefulness of chromosome damage as a biological marker of dose and cellular responsiveness. 


\section{Background}

The use of chromosome aberrations as a biological indicator of radiation exposure and dose have been reviewed (Bender et al. 1988). Aberration frequency has been used to evaluate radiation exposure in accidents where no physical dosimetry was present. These accidents included different exposure patterns and modes such as acute exposure to low LET radiation (Bender 1964, Bender and Gooch 1966) chronic exposure to radiation sources (Littlefield et al. 1990) internally deposited radioactive materials (Littlefield et al. 1983) and in many accidental exposures of unknown magnitude and extent (Lloyd and Edwards 1989). To use aberrations in biological dosimetry it is important to consider not only the target tissue but also to recognize that there are many biological and dosimetric variables that influence the magnitude and shape of dose-response relationships. Dose-response relationships have been characterized as a function of the LET of the ionizing radiation (Lloyd and Edwards 1983), the dose rate of the exposure (Brewen and Luippold 1971), the time between the exposure and sampling of the cells (Bender et al. $1985)$, distribution of the radiation dose both on a macro (Kleinerman et al. 1990) and micro (Brooks et al. 1974) scale.

Three major areas will be discussed using chromosome aberrations to characterize dose and response of cells. First, cytogenetic evaluation of tracheal epithelium and liver has provided data to convert exposure to dose. Second, studies will be discussed were aberrations were used to measure radiation induced changes in cell sensitivity. Finally, molecular probes were used to "paint 
chromosomes" (Lucus et al. 1989) which made it possible to quantitate the production and survival of symmetrical chromosome exchanges. These aberrations can survive cell division and may play a central role in the induction of cancer (Croce 1987).

\section{Methods and Results}

\section{A. Use of Chromosome Aberrations to Convert Environmental Exposure to Dose}

To calculate radiation dose from internally deposited radioactive materials it is necessary to measure the exposure, deposition and retention of radioactive material. To convert exposure to dose information is needed on the amount of radioactive material deposited in the tissue per unit of mass, its retention kinetics, the distribution in tissue and the energy and emission characteristics of the deposited radioactive material. For isotopes that are retained with a long effective half-lifes in the target tissue this information can be derived and used estimate radiation dose. The calculated dose can be related to biological changes such as chromosome aberrations. To help insure that this calculated dose-response relationship is accurate it must be related dose-response relationships for the frequency of aberration induced by radiation exposure where dose is measured by physical means. This combined biological and physical approach to dosimetry can be used for a variety of different environmental contaminations.

Liver cells were exposed to protracted low LET exposure from internally deposited ${ }^{144} \mathrm{Ce}$. The calculated dose-response is being 
compared to a measured dose-response relationship observed for liver cells exposed to chronic low LET gamma irradiation from $60 \mathrm{Co}$. The methods for ${ }^{144} \mathrm{Ce}$ injection, the liver retention functions and the calculated radiation dose to the liver per unit of ${ }^{144} \mathrm{C} \mathrm{e}$ deposited in the liver have been reported (Sturbaum et al. 1970). The methods used to stimulate the liver cells to divide, the experimental design and the scoring methods were previously reported, along with the dose-response relationships for chromosome aberration induction using the calculated radiation dose (Brooks et al.1972). These data are being compared those derived from an experiment where the animals were exposed to $60 \mathrm{Co}$ gamma rays for 6,15 or 42 days and the frequency of chromosome aberrations in the liver determined after well define dose and dose rate exposures (Brooks et al. 1971). The data from these two experiments are compared in Figure 1 where the cumulative radiation dose in $G y$ is plotted against the aberration frequency. For the ${ }^{144} \mathrm{Ce}$ the dose is calculated from the retention and distribution data for the isotope while the dose for the 60 Co was measured. The slopes of the dose response curves (Aberrations/cell $=0.02+3.1 X$ $10^{-2} \mathrm{D}$; Aberrations/cell $=0.02+3.3 \times 10^{-2} \mathrm{D}$ where $\mathrm{D}$ is dose in Gy) for the ${ }^{144} \mathrm{Ce}$ and $60 \mathrm{Co}$, respectively, were not significantly different. This shows that the calculated doses and the measured doses were similar and that per unit dose chromosome aberration frequency increased at the same rate for the two exposure schedules.

Chromosome aberration frequency was used to test models of exposure-dose relationships after exposure to high LET alpha 
particles. Tracheal epithelial cells were exposed either in vivo or in vitre to radon progeny. It is more difficult to determine the dose-response relationships for induction of chromosome aberrations by high LET radiation since it is not possible to make direct measurement of tissue dose. Models have been developed to calculate radiation dose to cells following exposure to alpha particles both in vitro (Jostes et al. 1991) and after inhalation of radon progeny in vive (James 1984, 1988). Details of the experimental design to compare aberrations produced in rat tracheal epithelial cells in vitro and after exposure to radon progeny at a single level have been reported (Brooks et al. 1992). Additional data is being reported here on damage from exposure to lower levels of radon ( 320 WLM) and additional information is included on doseresponse relationships in vitro to graded levels of alpha particles from $239 \mathrm{Pu}$. Figure 2 shows the slope of the dose response relationships for chromosome damage produced in tracheal epithelial cells from 239Pu alpha particles. Super-imposed on the figure are the data for the aberration frequency induced by inhalation of either 900 or 320 WLM or radon progeny. This makes it possible to estimate dose/WLM at the two different total exposures as $2.2 \mathrm{mGy} / \mathrm{WLM}$ and $3.0 \mathrm{mGy} / \mathrm{WLM}$ for the high and low dose exposures, respectively. It illustrates that per WLM the lower exposure level (320WLM) produced a higher frequency of chromosome aberrations than was induced by higher exposure levels. This could be related to alpha induced changes in cell cycle kinetics (Wolff et al. 1988) or cell killing induced by the higher doses. 


\section{B. Use of Chromosome Aberrations to Measure Radiation Induced Changes of Cell Sensitivity.}

Small doses of either tritium (Olivieri et al. 1984) or $x$ rays (Wolff et al. 1988) given in vitro decrease the frequency of chromosome aberrations observed in human blood lymphocytes induced by subsequent challenge doses of $x$ rays relative to the level observed without a "primer" dose.

Our studies to determined if chromosome aberration frequency can be used to determine if a chronic exposure of the bone marrow from internally deposited ${ }^{144} \mathrm{Ce}$ changes the responsiveness of the cells to subsequent ${ }^{\circ} \mathrm{Co}$ exposure. Chinese hamsters were injected with levels 0.0 or $0.85 \mathrm{kBq}{ }^{144} \mathrm{Ce} \mathrm{g}$ body weight. Animals were divided into four groups with equal numbers of males and females in each group: (1) controls injected with sodium citrate carrier solution (4 animals); (2) injected with ${ }^{144} \mathrm{Ce}$ ( 6 animals); (3) exposed to $60 \mathrm{Co}$ only ( 6 animals); (4) injected with ${ }^{144} \mathrm{Ce}$ and exposed to $60 \mathrm{Co}$ ( 6 animals). On the day of sacrifice hamsters were exposed to either 0 or 2.0 Gy of $60 \mathrm{Co}$ gamma rays delivered at an exposure rate of 2.1 Gy min; 7 hours later, each hamster was injected with 750 ul of colcemid and killed with halothane 2 hours later. Bone marrow cells were harvested as previously described (Bender et al. 1988) and 100 cells from each animal scored on coded slides (Brooks et al. 1971).

Table 1 shows the results of the experiment and illustrates that no significant difference were observed in the total aberration frequency following combined treatment with $60 \mathrm{Co}$ and ${ }^{144} \mathrm{Ce}$. The 
table demonstrates that the frequency of chromatid exchanges was increased by more than a factor of two by the ${ }^{\circ} \mathrm{Co}$ radiation exposure when the animals had a body burden of ${ }^{144} \mathrm{Ce}$ compared with animals without a ${ }^{144} \mathrm{Ce}$ body burden (Figure 3 ). This observation is difficult to explain since the cells have undergone multiple cell divisions during ${ }^{144} \mathrm{Ce}$ exposure and the cumulative damage induced by ${ }^{144} \mathrm{Ce}$ was not increased above the controls. It is difficult to postulate a direct mechanism of chromosome damage and interaction that would account for the observed increase in frequency of chromatid exchange type aberrations. There are at least two potential explanations that may account for the observation. First, chronic ${ }^{144} \mathrm{Ce}$ exposure caused a shift in the cell cycle in the bone marrow that resulted in more cells being in a sensitive stage of the cell cycle at the time of the $60 \mathrm{Co}$ radiation exposure (Hsu et al. 1962). This needs to be checked using flow cytometry but doesn't seem to be a viable mechanism since the total dose $(0.22 \mathrm{~Gy})$ and dose rate $(7.3 \mathrm{mGy} /$ day) were very low. The second postulated mechanism is that the chronic ${ }^{144} \mathrm{Ce}$ exposure induced repair enzymes which causes an increased the level of misrepair of the damage to result in a higher frequency of chromatid exchanges. Similar radiation induced repair enzymes have been demonstrated blood lymphocytes which decreased the frequency of chromatid deletions induced by a challenge dose (Olivieri et al.1984; Wolff et al. 1988). 


\section{Understand Mechanisms of Radiation Interactions}

Recent developments in molecular biology are being applied to cytogenetics to label specific regions of the chromosomes (Lichter et al. 1988, Pinkel et al. 1988. Moyzis et al. 1987, Meyne et al. 1989. Lucus et al. 1989). These techniques were expanded to "paint" whole chromosomes. This makes it possible to follow the fate of the chromosome after treatment with mutagenic or clastogenic agents. With these new techniques we have conducted studies to determine the kinetics of induction and the survival of symmetrical chromosome exchanges. $A_{L}$ cells were derived from Chinese hamster ovary cells (Waldren et al. 1986). They contain a single copy of human chromosome 11. By using human specific gene probes, chromosome 11 can be preferentially stained as published (Lucus et al. 1989). This makes it possible to identify changes in this chromosome and to follow its interactions with other chromosomes.

$A_{L}$ cells were exposed to graded doses of 60 Co gamma rays $(0.0$, 2.0, 4.0, 8.0 and 10.0 Gy) and harvested 24 hours after exposure for chromosome analysis. Only changes in chromosome 11 were recorded to determine the kinetics of aberration formation for each aberration type. Additional $A_{L}$ cells were exposed to either 0.0 or 8.0 Gy of 60 Co gamma rays and were sacrificed at $1,3,6,9$, and 13 days after the exposure. This study followed the changes in the frequency of symmetrical chromosome exchanges with time after exposure. At later times cell proliferation eliminates cells with unstable aberrations and may produce clones of cells with similar exchanges. The frequency of dicentrics, terminal exchanges, 
interstitial exchanges, deletions and rings which involved human chromosome 11 were recorded. There were 100 cells scored per experimental treatment on coded slides. Using this technique it was possible to quantitate the frequency of terminal translocations even when there was only a very small part of chromosome 11 translocated. It was noted that the dose-response kinetics for the induction of deletions and terminal translocations was not significantly different (Figure 3). This suggests that these two types of aberrations may be produced by similar mechanisms. These

data provide evidence that deletions are forms of incomplete exchanges as was postulated by Revelle(1959). The frequency of dicentrics was less than observed for the terminal translocations and if fact was very similar to that observed for interstitial translocations.

\section{Discussion}

This paper illustrates some of the multiple uses of chromosome aberrations; to convert exposure to radiation dose; to evaluate radiation induced changes in cell sensitivity; to act as biomarkers of radiation exposure and to help understand the mechanisms of interaction of radiation with cells.

Chromosome aberration frequency can be used to validate models of radiation exposure and determine if estimated doses from internally deposited radioactive materials are similar to measured doses. The examples cited using liver demonstrated that liver cells responded in a similar way following either ${ }^{60} \mathrm{Co}$ or ${ }^{144} \mathrm{Ce}$ exposure. 
This suggests that the calculated radiation dose from internally deposited ${ }^{144} \mathrm{Ce}$ is similar to the measured dose from $60 \mathrm{Co}$.

The radon dose calculated using chromosome damage as a biological dosimeter resulted in estimated doses (Gy/WLM) which are in reasonable agreement from published models (James 1984, 1988). This biological dosimetric approach may also have application in estimating radiation dose delivered to target organs and cells by environmental exposures and by radiation therapy using radiolabled monoclonal antibodies or other targeted organ or cell specific molecules.

Advances in molecular biology make it possible to address mechanistic questions using cytogenetics. With chromosome specific "paints" it is possible to evaluate the differences between different aberration types as a function of dose without the complication of between chromosome differences and problems in aberration identification and classification. This provided an understanding of how different types of aberrations are produced. Our current research suggested that terminal translocations and deletions are produced by similar "two hit" mechanisms (Revelle 1959) and that dicentrics and interstitial exchanges may have some common modes of production. Additional information is needed to define the repair and survival of these aberrations in dividing cell populations. Finally, there is a need to link new molecular techniques derived from research associated with the human genome to other fields which make it possible to develop more sensitive and specific markers of dose and environmental exposure. These molecular links to exposure and dose can be coupled with better 
cellular and molecular methods to define individual sensitivity and help provide a mechanistic base for development of risk from exposures.

\section{References}

Bender, M.A. (1964) Chromosome aberrations in irradiated human subjects, Ann. N.Y. Acad. Sci. 114, 249-251.

Bender, M.A., A.A. Awa, A.L. Brooks, H.J. Evans, P.G. Groer, L.G. Littlefield, C. Pereira, R.J. Preston, B.W. Wachholz, (1988) "Current status of cytogenetic procedures to detect and quantify previous exposures to radiation", Mutation Res, 196, 103-159.

Bender, MA, and P.C. Gooch (1966) Sor icic chromosome aberrations induced by human irradiation: the "recuplex" criticu'; c cident, Radiat. Res. 29, 568582.

Brewen, J.G., H.E. Luippold (1971) Radiation-induced human chromosome aberrations: in vitro dose rate studies, Mutation Res. 12, 305-314.

Brooks, A.L. D.K. Mead and R.F. Peters (1971) Effects of chronic exposure to $60 \mathrm{Co}$ on the frequency of metaphase chromosome aberrations in the liver cells of the Chinese hamster (in vivo) Int. J. Radiat. Biol. 20, 599-604.

Brooks, A.L. R.O. McClellan, and S.A. Benjamin, (1972) "The effects of ${ }^{144} \mathrm{Ce}$ $144 \mathrm{Pr}$ on the metaphase chromosomes of the Chinese Hamster liver cells in vivo. Radiat. Res. 52, 481-498.

Brooks, A.L., J.C. Retherford, R.O. McClellan (1974) Effect of 239-Plutonium oxide particle number and size on the frequency and distribution of chromosome aberrations in the liver of the Chinese hamster, Radiat. Res. 59, 693-709.

Brooks, A.L. , K. Rithidech, R.M. Kitchin, N.F. Johnson, D.G. Thomassen, D.G., and Newton, G.J., (1992) Evaluating Chromosome damage to estimate dose to tracheal epithelial cells, Indoor Radon and Lung Cancer: Reality or Myth?, Twenty-Ninth Hanford Symposium on Health and the Environment (In Press).

Croce, C.M. (1987) Role of chromosome translocations in human Neoplasia, Cell 49, 155-156. 
Fenech, M. and A.A. Morely (1985) Measurt ent of micronuclei in lymphocytes. Mutat. Res. 147, 29-36.

Harley, N.H. and B.S. Pasternack, B.S. (1972) Alpha absorption measurements applied to lung dose from radon daughters, Health Phys. 23, 771-782.

Hsu, T.C., W.C. Dewey and R.M. Humphrey (1962) Radiosensitivity of cells of Chinese hamster in vitro in relation to the cell cycle, Experi Cell Res. 27, 441452.

James, A. C. (1988) Lung dosimetry. Radon and its decay products in indoor air, W.W. Nazaroff and $A$ V. Nero (eds) Willey Interscience, New York, pp. 259-309.

James, A.C. (1984) Dosimetric Approaches to risk assessment from indoor exposure. Radiat. Prot. Dosim. 7(1-4): 353-366.

Jostes, R.W., T.E. Hui, A.C. James, F.T. Cross, J.L. Schwartz, J. Rotemsch, R. W. Atcher, H.H. Evans, J. Mencel, G. Gakale, P.S. Rao, (1991) In Vitro Exposure of Mammalian Cells to Radon: Dosimetric Considerations, Radiat. Res. 127, 211-219.

Kleinerman, R.A., L. G. Littlefield, R.E. Tarone, A.M. Sayer, N.G. Hildretgh, L.M. Potter, S.G. Machado, and J.D. Boikce Jr., (1990) Chromosome aberrations in relation to radiation dose following partial-body exposure in three populations. Radiat. Res. 123, 93-101.

Lloyd D.C. and A.A. Edwards, (1989) Biological Dosimetry after Radiation Accidents, in; Chromosomal Aberrations, Basic and Applied Aspects, Ed: G.Obe and A.T. Natarajan, Springer-Verlag Berlin Heidelberg pp. 212-223.

Littlefield, L.G., E.E. Joiner, S.P. Colyer, R.C. Ricks, C.C. Lushbaugh, R. Hurado-Monroy (1991) The 1989 San Salvador $60^{\circ}$ Co radiation accident: Cytogenetic dosimetry and follow-up evaluation in three accident victims. Radiat. Prot. Dosim. 35, 115-123.

Littlefield, L.G., E.E. Joiner, R.J. DuFrain, S. Colyer, B. Breitenstein, (1983) Six year cytogenetic follow-up study of an individual heavily contaminated with Americum-241, in: J.J. Broerse, G.W. Barendsen, H.B.KKal, A.J. Van der Kogel (Eds). Proceedings of the seventh International Congress of Radiation Research, Dosimetry, Radionuclides and Technology Sessions E3-05. Martinus, Nijhoff, Amsterdam.

Lichter, P. Cremer, T. Tang, C.C. Watkins, P.C. Manuelidis, L. Ward, D.C . (1988) Rapid detection of human chromosome 21 aberrations by in situ hybridization. Proc. Natl. Acad. Sci. USA 85, 9664-9668. 
Lloyd, D.C. and A.A. Ed'rards, (1983) Chromosome aberrations in human lymphocytes: effects of radiation quality, dose and dose rate, in: Radiation Induced Chromosome Damage in Man, Liss, New York, pp. 23-49.

Lloyd, D.C., A.A. Edwards, A. Leonard, G.L. Deknudt, L. Verschaeve, A.T. Natarajan, F. Darroudi, G. Obe, F. Palitti, C. Tanzarella, E.J. Tawn, (1992), Chromosomal aberrations in human lymphocytes induced in vitro by very low doses of X-rays, Int. J. Radiat. Biol, 61,335-343.

Lucas, J.N., T. Tenjin, R. Straume, D. Pinkel, D. Moore, M. Litt, J.W. Gray (1989) Rapid human chromosome aberration analysis using fluorescence in situ hybridization. Int J Radiat Biol 56, 35-44.

Meyne, J., Littlefield, L.G., Moyzis, R.K. (1989) Labeling of human centromeres using alphoid DNA consensus sequence: application to the scoring of chromosome aberrations. Mutat. Res. 226: 75-79.

Moyzis, R.K., K.L. Albright, M.F. Bartholdi,L.S. Cram, L.L. Deaven, C.E. Hildebrand, N.E. Joste, J. Meyne, T. Schwarzacher-Robinson (1987) Human chromosome-specific repetitive DNA sequences: Novel markers for genetic analysis, Chromosoma (Berl) 95, 375-386.

Olivieri, G., J. Bodycote and S. Wolff (1984) Adaptive response of human lymphocytes to low concentrations of radioactive thymidine, Science, 223, 594-597.

Pinkel, D., J. Landegent, C. Collins, J. Fusco, R. Segraves, J. Lucas, J.W. Gray (1988) Fluorescence in situ hybridization with human chromosome-specific libraries: detection of trisomy 21 and translocations of chromosome 4, Proc. Natl. Acad. Sci. USA 85, 9138-9142.

Revell, S.H. (1959), The accurate estimation of chromatid breakage in its relevance to a new interpretation of chromatid aberration induced by ionizing radiation. Proc. Roy. Soc. London 150, 563-572.

Sandberg, A.A. T-C.Claude, R.M. Gemmill, (1988) Chromosomes in solid tumors and beyond, Cancer Research 48, 1049-1059.

Sturbaum, B., A.L. Brooks, R.O. McClellan (1970) Tissue distribution and dosimetry of $144 \mathrm{Ce}$ in Chinese hamsters, Radiat. Res. 44, 359-367.

Waldren, C., L. Correll, M.A. Sognier, and T.T. Puck. (1986) Measurement of low levels of $x$-ray mutagenesis in relation to human disease. Proc. Natl. Acad. Sci. USA 83, 4839-4843. 
Wolff, S. V. Afzal, J.K. Wiencke, G. Olivieri and A. Michaeli (1988) Human lymphocytes exposed to low doses of ionizing radiations become refractory to high doses of radiation as well as to chemical mutagens that induce doublestrand breaks in DNA, Int. J. Radiat. Biol. 53, 39-48.

Research upported by OHER U.S. Department of Energy DEAC06-76RLO 1830 and NIH RO1 CA45590.

\section{FIGURES LEDGENDS}

Figure 1. Comparison of calculated dose-response relationships for the induction of chromosome aberrations by internally deposited ${ }^{144} \mathrm{Ce}$ to measured dose-response relationships for induction of aberrations after chronic external exposure to $60 \mathrm{Co}$.

Figure 2. Conversion of WLM to dose in Gy using chromosome aberrations in an vitro/in vivo technique for exposure to radonprogeny.

Figure 3. The interaction of damage from a ${ }^{144} \mathrm{Ce}$ body burden and acute ${ }^{60} \mathrm{Co}$ on the induction of chromatid exchanges in the bone marrow of Chinese hamsters.

Figure 4. Induction kinetics of chromosome deletions and symmetrical chromosome exchanges in $A_{L}$ cells following exposure to graded doses of $60 \mathrm{Co}$. 


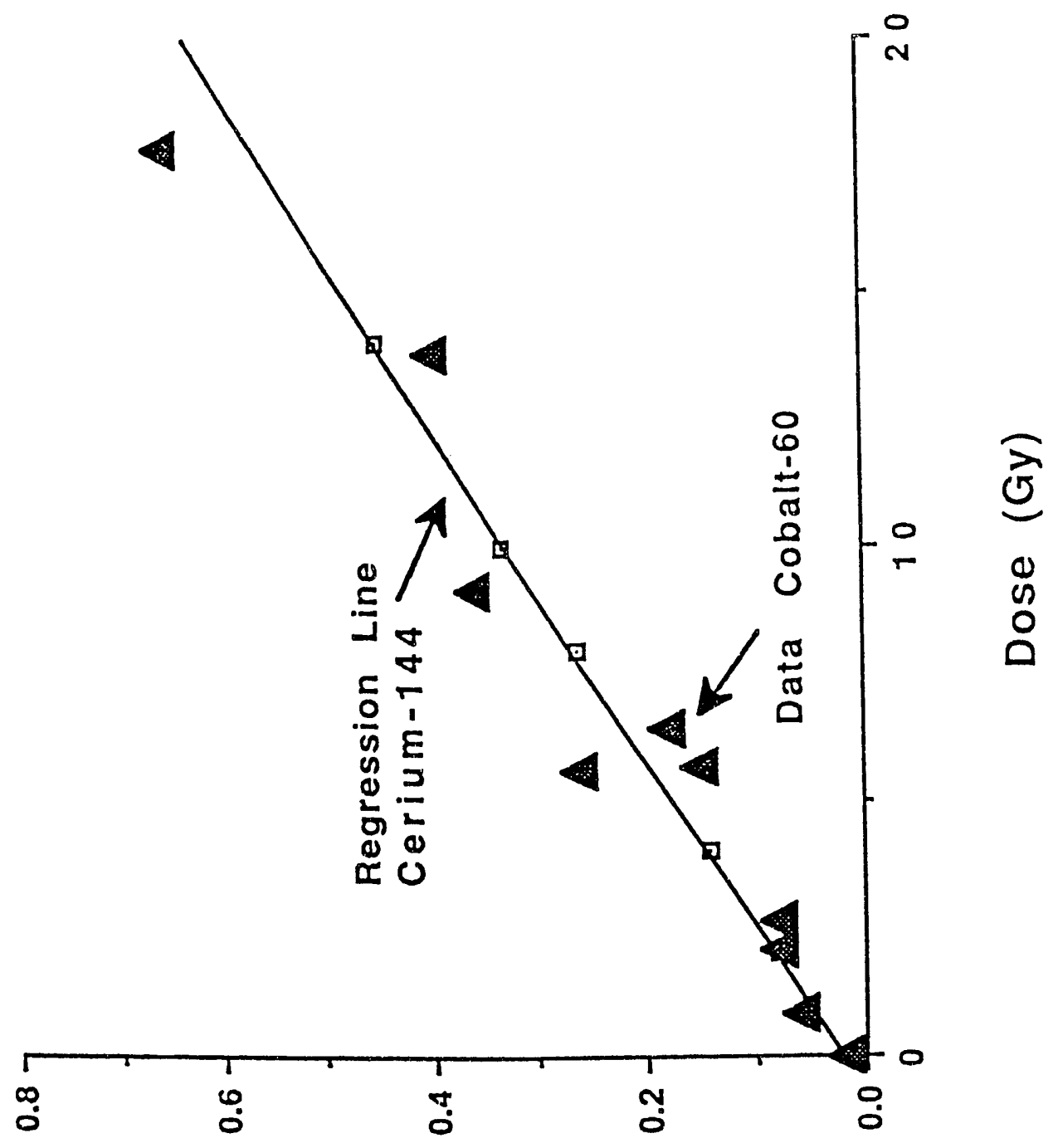

IIəo/suo!ฺeddəq 


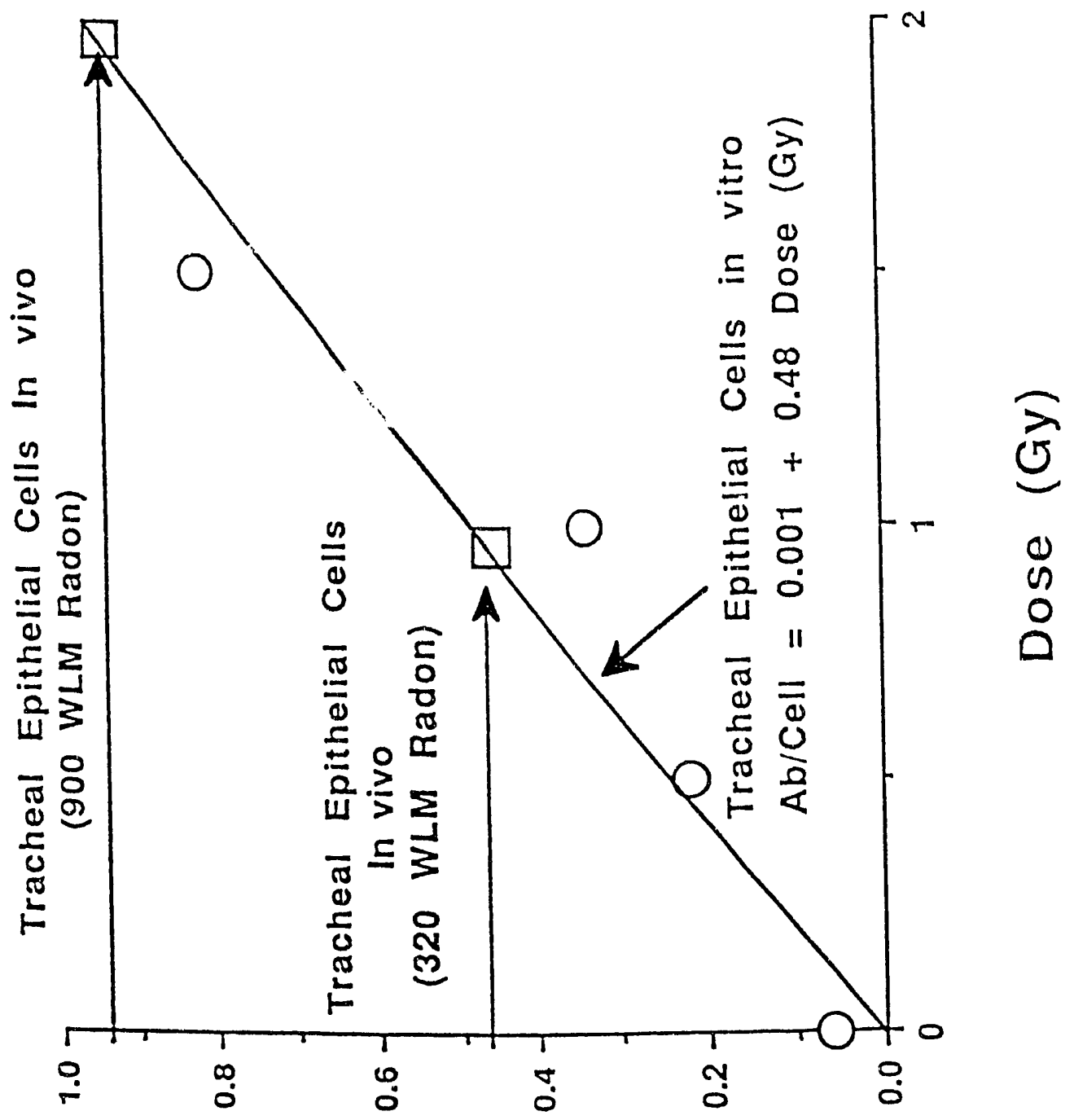

IIәว/suo!ाeddəq 
Chromatid Exchanges/Cell

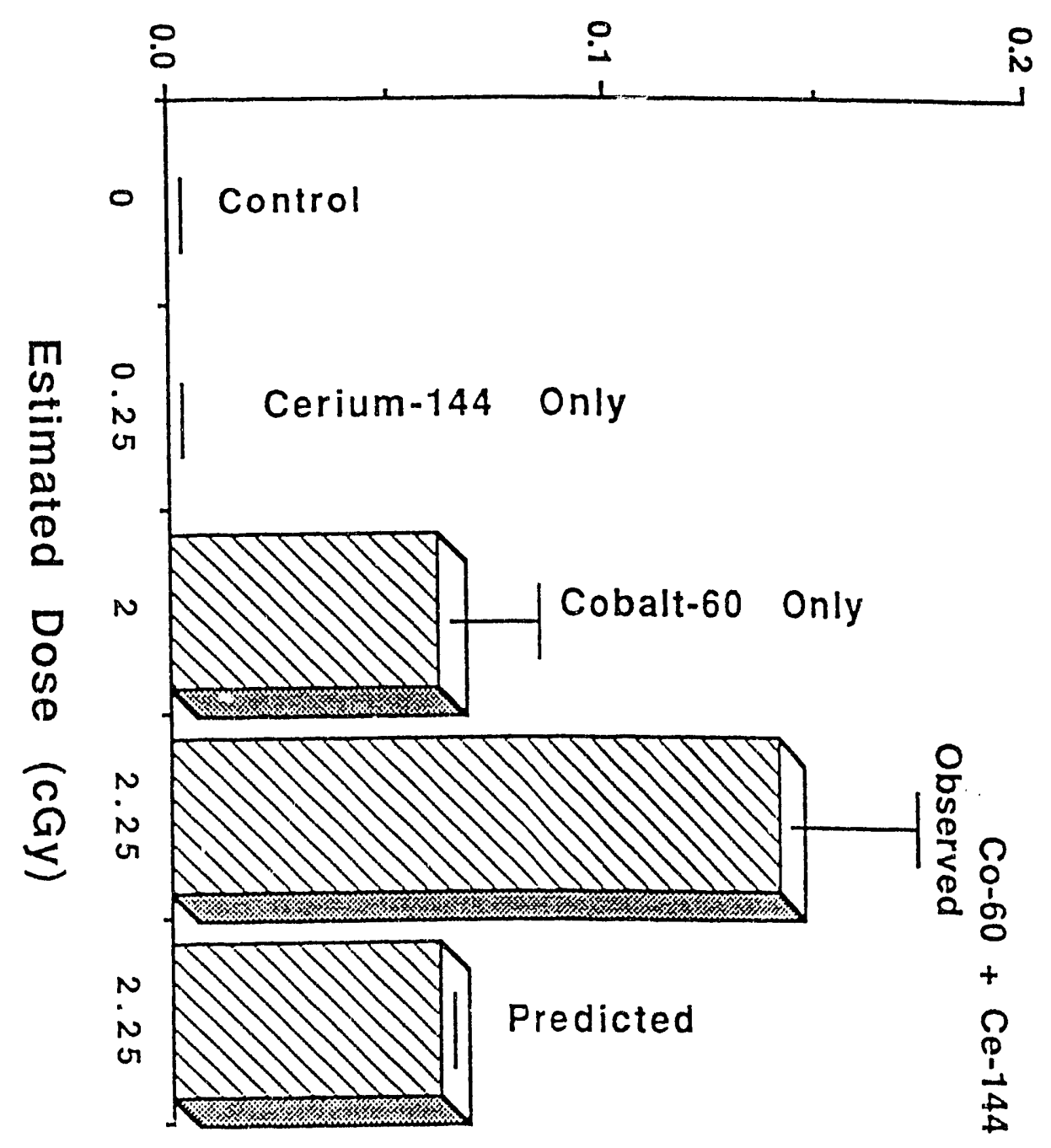




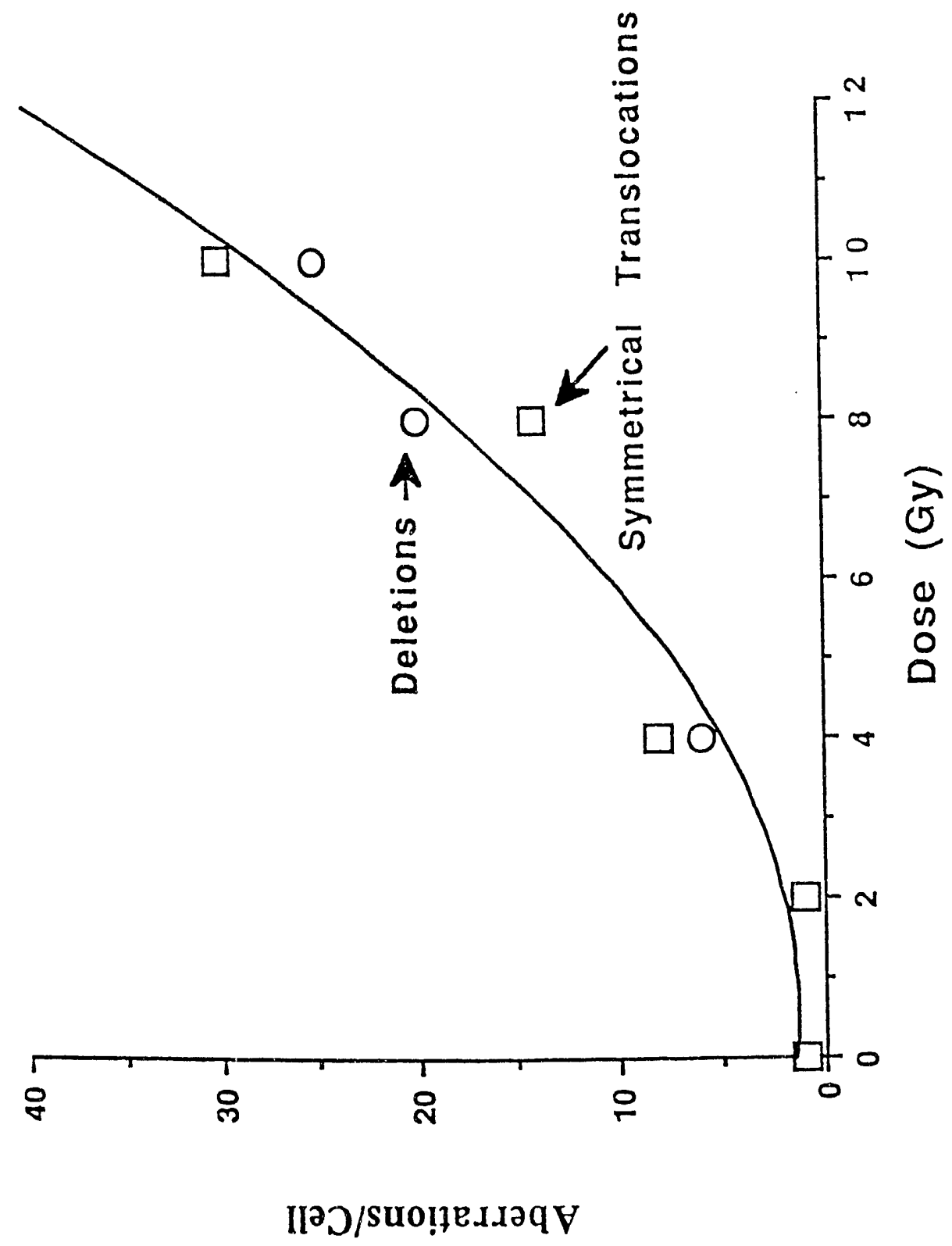



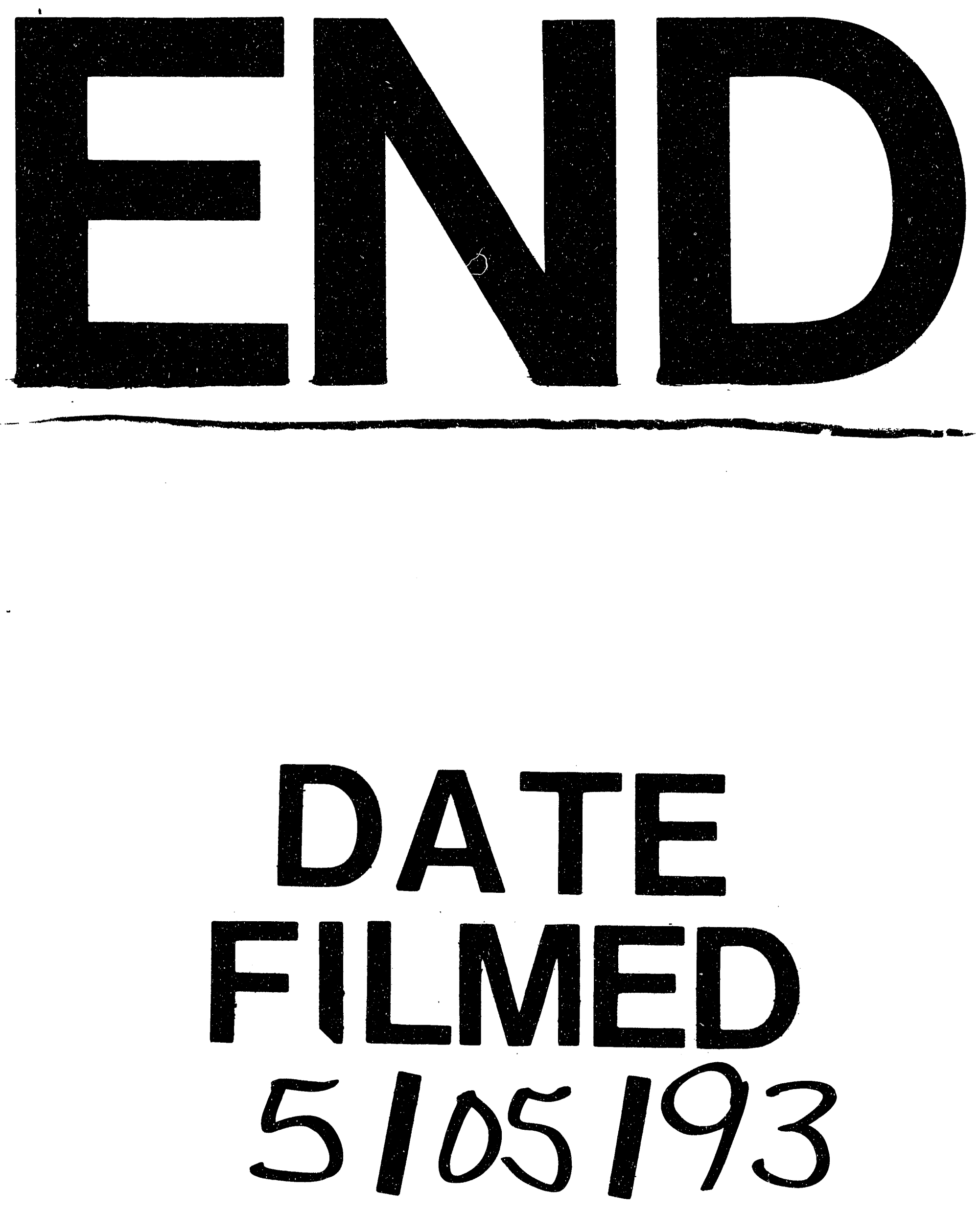
| 